\title{
DOSTĘP DO WYMIARU SPRAWIEDLIWOŚCI W SPRAWACH DOTYCZĄCYCH ŚRODOWISKA - TRANSPOZYCJA TRZECIEGO FILARU KONWENCJI Z AARHUS DO PRAWA UNII EUROPEJSKIEJ
}

\section{ACCESS TO JUSTICE IN ENVIRONMENTAL MATTERS - TRANSPOSITION OF THE THIRD PILLAR OF THE AARHUS CONVENTION INTO THE EUROPEAN UNION LAW}

\section{STRESZCZENIE}

Celem opracowania jest omówienie problematyki wdrożenia do prawa Unii Europejskiej postanowień Konwencji z Aarhus w zakresie

" Adiunkt w Katedrze Prawa Europejskiego na Wydziale Prawa i Administracji UMK w Toruniu. 
dostępu do wymiaru sprawiedliwości w sprawach dotyczących środowiska, a w szczególności postanowień art. 9 ust. 3 Konwencji oraz kompetencji Trybunału Sprawiedliwości w zakresie interpretacji jej postanowień w tym obszarze.

\section{Słowa kluczowe}

Konwencja z Aarhus; dostęp do wymiaru sprawiedliwości; ochrona środowiska; skutek bezpośredni.

\section{ABSTRACT}

The aim of this article is to present the problem of access to justice in environmental matters, the obligations of Member States and the EU under article 9(3) of the Aarhus Convention and the allocation of jurisdiction to interpret provisions of mixed agreements between national courts and the Court of Justice.

Keywords

Aarhus Convention; access to justice; environment protection; direct effect.

\section{WPROWADZENIE}

W dniu 25 czerwca 1998 r. Wspólnota ${ }^{1}$ podpisała Konwencję Europejskiej Komisji Gospodarczej ONZ (EKG ONZ) o dostępie do informacji, udziale społeczeństwa w podejmowaniu de-

1 Reforma ustrojowa Unii Europejskiej dokonana Traktatem z Lizbony (Traktat z Lizbony zmieniający Traktat o Unii Europejskiej i Traktat ustanawiający Wspólnotę Europejską, sporządzony w Lizbonie dnia 13 grudnia 2007 r., Dz.U. z 2009 r. Nr 203, poz. 1569) nadała Unii Europejskiej osobowość prawnomiędzynarodową (art. 47 Traktatu o Unii Europejskiej dalej: TUE). Jednocześnie, zgodnie z art. 1 TUE, Unia zastąpiła Wspólnotę Europejską i stała się jej następcą prawnym. Szerzej na ten temat porównaj: Ł. Baumgart, Sukcesja prawnomiędzynarodowa pomiędzy Unia Europejska a wspólnotami europejskimi oraz innymi organizacjami międzynarodowymi, „Studia Prawnicze” 2011, z. 3/4, s. 293-319. Wersja skonsolidowana Traktatu o Unii Europej- 
cyzji oraz dostępie do sprawiedliwości w sprawach dotyczących środowiska (zwaną dalej „Konwencją z Aarhus”)2. Podstawowym celem Konwencji było zwiększenie przejrzystości i jawności działań władz publicznych w sprawach dotyczących środowiska oraz wprowadzenie gwarancji umożliwiających kontrolę społeczną tych działań.

Struktura Konwencji z Aarhus opiera się na trzech filarach: dostępie do informacji, udziale społeczeństwa w podejmowaniu decyzji oraz dostępie do wymiaru sprawiedliwości ${ }^{3}$.

Zgodnie z postanowieniami art. 9 Konwencji prawo do wymiaru sprawiedliwości obejmuje następujące aspekty: po pierwsze, zapewnia dostęp do postępowania odwoławczego każdej osobie, której wniosek o udostępnienie informacji dotyczących środowiska został odrzucony lub z innych względów nierozpoznany (ust. 1). Po wtóre, umawiające się strony zobowiązały się do zapewnienia, w ramach ich krajowego porządku prawnego, że „członkowie zainteresowanej społeczności”, którzy spełniają określone kryteria ${ }^{4}$, będą mieli dostęp do postępowania

skiej i Traktatu o funkcjonowaniu Unii Europejskiej (dalej: TFUE), Dz.Urz. UE C 326 z 26.10.2012, s. 1.

2 Konwencja o dostępie do informacji, udziale społeczeństwa w podejmowaniu decyzji oraz dostępie do sprawiedliwości w sprawach dotyczących środowiska podpisana w Aarhus w dniu 25 czerwca 1998 r. i zatwierdzona w imieniu Wspólnoty Europejskiej decyzją Rady 2005/370/WE z dnia 17 lutego 2005 r., Dz.Urz. UE L 124 z 17.5.2005, s. 1.

3 W doktrynie problematyka dostępu do wymiaru sprawiedliwości doczekała się licznych komentarzy: J. Ciechanowicz-McLean, Prawo i polityka ochrony środowiska, Warszawa 2009, s. 146-147; J. H. Jans, Who is the Referee? Access to Justice in a Globalised Legal Order, „Review of European Administrative Law" 2011, Vol. 4 Issue 1, s. 85-97; J. Jendrośka, M. Bar, Implementation of the Aarhus Convention principles and other topical issues of EU environmental law as reviewed in a critical analysis of the Yearbook of European Environmental Law - Vol. 4 i 5, „Environmental Liability Journal”, Vol. 14 (5) 2006, s. 192-205; A. Lidbetter, N. Depani, The Aarhus Convention and Judicial Review, „Judicial Review” 2014, Vol. 19 Issue 1, s. 30-38, DOI: 10.5235/JR.23.2.1; B. Müller, Access to the Courts of the Member States for NGOs in Environmental Matters under European Union Law, „Journal of Environmental Law” Nov 2011, Vol. 23 Issue 3, s. 505-516.

4 Konwencja wskazuje na wystarczający interes oraz naruszenie uprawnień. Określenie tego, co stanowi wystarczający interes oraz naruszenie uprawnień, następuje zgodnie z wymaganiami prawa krajowego i stosownie 
odwoławczego pozwalającego na zakwestionowanie legalności każdej decyzji, działania lub zaniechania w sprawach regulowanych postanowieniami art. 6 Konwencji. Strony mogą przy tym powoływać się na uchybienia materialne lub formalne (ust. 2). Ponadto, prawo do sądu obejmuje obowiązek zapewnienia w prawie krajowym, że „członkowie społeczeństwa” spełniający wymagania określone $\mathrm{w}$ tym prawie będą mieli dostęp do administracyjnego lub sądowego postępowania umożliwiającego kwestionowanie działań lub zaniechań władz publicznych naruszających przepisy prawa krajowego w dziedzinie środowiska (ust. 3). Konwencja nakłada także na strony zobowiązanie do przyjęcia takich rozwiązań proceduralnych, które gwarantują odpowiednie i prawnie skuteczne środki zaradcze, oraz wyznacza istotne standardy, z którymi takie procedury powinny być zgodne: bezstronności, równości, terminowości i niedyskryminacji ze względu na koszty (ust. 4). Umawiające się strony zostały także zobowiązane do informowania społeczeństwa o jego prawie dostępu do administracyjnych lub sądowych środków odwoławczych oraz obliguje je do rozważenia kwestii stworzenia odpowiedniego mechanizmu udzielania pomocy służącego zapewnieniu szerszego dostępu do wymiaru sprawiedliwości (ust. 5).

Dostęp do wymiaru sprawiedliwości o którym mowa w art. 9 Konwencji obejmuje zatem swoim zakresem wyłącznie postępowania $\mathrm{w}$ sprawach wynikających $\mathrm{z}$ naruszenia prawa do informacji i udziału w podejmowaniu decyzji w sprawach dotyczących środowiska ${ }^{5}$. Omawiane prawo realizuje dwa podstawowe cele: kontrolny i gwarancyjny. Podmioty zainteresowane mają możliwość kontroli osób fizycznych, prawnych oraz organów władzy publicznej pod kątem przestrzegania prawa ochrony środowiska. Konwencja gwarantuje także możliwość

do celu, jakim jest przyznanie zainteresowanej społeczności szerokiego dostępu do wymiaru sprawiedliwości w zakresie określonym w niej.

5 Por. M. M. Kenig-Witkowska, Prawo środowiska Unii Europejskiej: Zagadnienia systemowe, Warszawa 2011, s. 30. 
odwołania w postępowaniach dotyczących udzielenia dostępu do informacji o środowisku ${ }^{6}$.

\section{WDROŻENIE POSTANOWIEŃ TZW. TRZECIEGO FILARU KONWENCJI Z AARHUS DO PRAWA UNII EUROPEJSKIEJ}

Ze względu na to, że stronami Konwencji z Aarhus są Unia oraz państwa członkowskie stanowi ona przykład umowy międzynarodowej o charakterze mieszanym. Taką konstrukcję uzasadnia zakres kompetencji Unii w dziedzinie środowiska, która zgodnie z art. 4 ust. 2 TFUE dzieli uprawnienia prawodawcze w tym obszarze z państwami członkowskimi. W konsekwencji, zgodnie z art. 216 ust. 2 Traktatu o funkcjonowaniu Unii Europejskiej (dalej: TFUE) ${ }^{7}$, jej postanowienia wiążą zarówno instytucje Unii, jak i państwa członkowskie ${ }^{8}$.

Umowy mieszane zawierane przez Unię Europejską są $\mathrm{w}$ rozumieniu prawa międzynarodowego wiążące dla niej wobec pozostałych stron. Obowiązywanie tego rodzaju umów w prawie wewnętrznym UE nie jest jednak zagadnieniem prawa międzynarodowego, lecz zagadnieniem prawa europejskiego, cechującym się pewną autonomią w zakresie zarówno wykładni postanowień umowy oraz jej skutków w sporach indywidualnych przed organami Unii Europejskiej oraz organami administracyjnymi i sadami krajowymi.

Zgodnie z zasadą pomocniczości, określoną w art. 5 ust. 3 TFUE, wdrażając postanowienia w dziedzinach, które nie należą do jej wyłącznej kompetencji, Unia podejmuje działania legislacyjne wyłącznie w sytuacji, gdy są one bardziej efektyw-

6 Por. J. Ciechanowicz-McLean, Prawo i polityka..., s. 55. Por. także uwagi M. Micińskiej, Udział społeczeństwa $w$ ochronie środowiska. Instrumenty administracyjno - prawne, Toruń 2011, s. 47.

7 Wersja skonsolidowana Traktatu o funkcjonowaniu Unii Europejskiej opublikowana w Dz.Urz. UE 2012 C 326, s. 1.

8 Szerzej na temat pozycji międzynarodowych umów mieszanych w prawie Unii Europejskiej por.: M. Niedźwiedź, Umowy międzynarodowe mieszane $w$ świetle prawa Wspólnoty Europejskiej, Warszawa 2004. 
ne niż indywidualne działania państw członkowskich. Konsekwencją wprowadzenia regulacji na poziomie unijnym jest to, że państwa członkowskie tracą możliwość wykonywania kompetencji w polu regulacji zajętym przez akt unijny i pole to staje się kompetencją wyłączną UE ${ }^{9}$. Do obszarów, które mogą być efektywniej realizowane na poziomie UE, zaliczyć należy wynikające z art. 9 Konwencji z Aarhus obowiązki zapewnienia zainteresowanym podmiotom dostępu do wymiaru sprawiedliwości w sprawach z zakresu środowiska ${ }^{10}$.

Unia Europejska podjęła szereg działań mających na celu wprowadzenie na poziomie unijnym regulacji obejmujących dostęp do wymiaru sprawiedliwości. Zobowiązania określone w art. 9 ust. 2 i 4 Konwencji z Aarhus zostały włączone do prawa europejskiego dyrektywą 2003/35/WE ${ }^{11}$.

W celu wypełnienia zobowiązań, które wynikają z art. 9 ust. 3 Konwencji przyjęte zostało natomiast rozporządzenie nr 1367/2006 ${ }^{12}$, które obejmuje jednak wyłącznie instytucje Unii Europejskiej. Zdecydowanie więcej trudności, co zostało zasygnalizowane już na etapie podpisywania Konwencji przez Wspólnotę/Unię, wiązało się z przygotowaniem unijnej regulacji nakładającej analogiczne zobowiązania na państwa członkowskie. W załączonej do Konwencji deklaracji określającej zasady podziału odpowiedzialności pomiędzy WE/UE a państwa członkowskie za wypełnienie wynikających z niej zobowiązań

9 J. Kranz, A. Wyrozumska, Powierzenie Unii Europejskiej niektórych kompetencji a traktat fiskalny, „Państwo i Prawo” 2012, nr 7, s. 20.

10 Szerzej na temat kompetencji UE i państw członkowskich do stanowienia prawa w dziedzinie środowiska por. M. M. Kenig-Witkowska, Prawo środowiska ..., s. 119 i n.

11 Dyrektywa Parlamentu Europejskiego i Rady z dnia 26 maja 2003 r. przewidująca udział społeczeństwa w odniesieniu do sporządzania niektórych planów i programów w zakresie środowiska oraz zmieniająca w odniesieniu do udziału społeczeństwa i dostępu do wymiaru sprawiedliwości dyrektywy Rady 85/337/EWG i 96/61/WE, Dz.Urz. UE L 156 25.06.2003, s. 17.

12 Rozporządzenia (WE) Parlamentu Europejskiego i Rady z dnia 6 września 2006 r. w sprawie zastosowania postanowień Konwencji z Aarhus o dostępie do informacji, udziale społeczeństwa w podejmowaniu decyzji oraz dostępie do sprawiedliwości w sprawach dotyczących środowiska do instytucji i organów Wspólnoty (Dz.Urz. UE L 264 25.9.2006, s. 13). 
wskazano, że „obowiązujące instrumenty prawne nie obejmują w pełni realizacji obowiązków wynikających z art. 9 ust. 3 Konwencji, jako że odnoszą się one do procedur administracyjnych i sądowych mających na celu kwestionowanie działań i zaniechań osób prywatnych i władz publicznych innych niż instytucje Wspólnoty Europejskiej objęte art. 2 ust. 2 lit. d) Konwencji (...) [W] wyniku tego (...) państwa członkowskie są odpowiedzialne za wykonanie tych obowiązków w momencie zatwierdzenia Konwencji przez Wspólnotę Europejską i nie zmieni się to, o ile i do czasu, gdy Wspólnota, wykonując swoje uprawnienia na mocy traktatu WE, przyjmie przepisy prawa wspólnotowego obejmujące wykonanie tych obowiązków"13.

Prace podjęte nad projektem dyrektywy nakładającej na państwa członkowskie zobowiązanie wprowadzenia wymogów określonych w art. 9 ust. 3 Konwencji zostały zaniechane w 2003 r. ${ }^{14}$ W 2013 r. Komisja, motywowana stanowiskiem Trybunału Sprawiedliwości nakładającym na państwa członkowskie obowiązek interpretacji krajowych norm w zgodzie $\mathrm{z}$ przepisami Konwencji, ponownie podjęła jednak działania zmierzające do przygotowania projektu dyrektywy i ogłosiła konsultacje społeczne w tym obszarze ${ }^{15}$.

Wobec braku unijnych regulacji nakładających na państwa członkowskie obowiązek wprowadzenia wymogów określonych w art. 9 ust. 3 Konwencji ujawnił się natomiast problem, w jaki sposób rozgraniczyć spoczywające na Unii i obowiązki ciążące wyłącznie na państwach członkowskich obowiązki zapewnienia dostępu do wymiaru sprawiedliwości. W szczególności istotnym z praktycznego punktu widzenia pytaniem jest to, czy postanowienia Konwencji określone w tym przepisie mogą wywołać skutek bezpośredni, a zatem czy jednostka może powołać się na tą regulację przed sądem krajowym oraz

13 Załącznik do decyzji 2005/370 zawierający deklarację Wspólnoty (Unii) złożoną zgodnie z art. 19 ust. 5 Konwencji z Aarhus.

14 Projekt dyrektywy Parlamentu Europejskiego i Rady w sprawie dostępu do wymiaru sprawiedliwości w sprawach dotyczących środowiska z dnia 24 października 2003 r., $\operatorname{COM(2003)} 624$ final.

15 Commission initiative on Access to justice in environmental matters at Member State level in the field of EU environment policy, listopad 2013. 
który sad, unijny czy krajowy ma jurysdykcję do dokonywania postanowień Konwencji ${ }^{16}$ ?

Odpowiedź na te pytania została udzielona przez Trybunału Sprawiedliwości w wyroku w sprawie C-240/09 Lesoochranárske zoskupenie ${ }^{17}$. Orzeczenie wydane zostało na skutek pytania prejudycjalnego dotyczącego wykładni art. 9 ust. 3 Konwencji z Aarhus z którym zwrócił się Słowacki Sąd Najwyższy w ramach rozstrzygania sporu między stowarzyszeniem Lesoochranárske zoskupenie VLK, a Ministerstwem Ochrony Środowiska Republiki Słowackiej. Spór krajowy dotyczył wniosku stowarzyszenia o uznanie jego legitymacji procesowej w postępowaniu administracyjnym w sprawie przyznania odstępstw od systemu ochrony niedźwiedzia brunatnego. Stowarzyszenie kwestionowało prawidłowość decyzji wydanej przez Ministerstwo, w której odmówiono mu statusu strony postępowania administracyjnego, wywodząc prawo do uczestnictwa w tym postępowaniu bezpośrednio z art. 9 ust. 3 Konwencji z Aarhus. W swojej opinii rzecznik generalna Eleanor Sharpston, uznała, że Trybunał jest właściwy do zbadania kwestii podziału kompetencji między Unię i jej państwa członkowskie. Trybunał ma także kompetencję do określenia zobowiązań, jakie Unia przyjęła na siebie przystępując do Konwencji z Aarhus. Uznanie braku kompetencji Trybunału w tym obszarze zwiększałoby w jej ocenie niepewność prawa dla Unii, państw członkowskich, państw trzecich oraz potencjalnych stron postępowań, jak również mogłoby prowadzić do odpowiedzialności UE z tytułu wadliwego wykonywania zobowiązań wynikających z Konwencji ${ }^{18}$. Trybunał Sprawiedliwości podzielił opinię rzecznika w tym zakresie. Analizując normę art. 9 ust. 3, TSUE trafnie wskazał, że jest

16 Szerokie omówienie pojęcia skutku bezpośredniego norm umów mieszanych w prawie międzynarodowym i unijnym por. J. Barcz, $W$ sprawie bezpośredniego skutku przepisów TRIPS $w$ świetle prawa wspólnotowego (I), „Europejski Przegląd Sądowy" 2006, nr 2, s. 18-30.

17 Wyrok Trybunału Sprawiedliwości UE z dnia 8 marca 2011 r. w sprawie C-240/09 Lesoochranárske zoskupenie, Zb. Orz. TE [2011] I-1255.

18 Opinia przedstawiona w dniu 15 lipca 2010 r. w sprawie C-240/09 Lesoochranárske zoskupenie VLKv. Ministerstvo životného prostredia Slovenskej republiky, Zb. Orz. TE [2011] I-1255, pkt. 59-61. 
ona pozbawiona bezpośredniej skuteczności na gruncie prawa Unii. Podkreślił, natomiast szczególną rolę sądu krajowego, którego zadaniem jest dokonanie - w zakresie, w jakim jest to tylko możliwe - wykładni krajowych przepisów proceduralnych dotyczących przesłanek, które winny zostać spełnione, aby móc wszcząć postępowanie administracyjne lub sądowe zgodnie z celami art. 9 ust. 3. Wykładnia prawa krajowego powinna zatem zapewniać skuteczną ochronę sądową uprawnień wynikających z prawa Unii, a w konsekwencji umożliwiać podmiotom wskazanym w art. 9 ust. 3 Konwencji zaskarżenie do sądu decyzji wydanej po przeprowadzeniu postępowania administracyjnego, które mogło być sprzeczne z unijnym prawem ochrony środowiska.

Wyrok w sprawie Lesoochranárske zoskupenie VLK można uznać za próbę uzupełnienia luki w prawie unijnym, wynikającej z zaniechania w 2003 r. działań legislacyjnych Komisji zmierzających do wdrożenia zobowiązań wynikających z art. 9 ust. 3 Konwencji ${ }^{19}$. Jak słusznie jednak podkreśla się w doktrynie, stanowisko Trybunału w zakresie zakresu obowiązywania art. 9 ust. 3 Konwencji w prawie UE jest co najmniej niejednoznaczne $^{20}$.

Konwencja z Aarhus nie zawiera postanowień dotyczących tego, jakie skutki ma wywierać art. 9 ust. $3 \mathrm{w}$ porządku prawnym Unii i jej państw członkowskich. W takiej sytuacji rozgraniczenie obowiązków spoczywających na UE i obowiązków ciążących na państwach członkowskich wymaga ustalenia, czy w dziedzinie objętej przez wskazany artykuł Unia skorzystała ze swych uprawnień i wydała przepisy dotyczące wykonania obowiązków, które z niego wynikają.

19 Por. Komunikat Komisji z 7 marca 2012 r. do Parlamentu Europejskiego, Rady, Europejskiego Komitetu Ekonomiczno-Społecznego i Komitetu Regionów: Lepsze wykorzystanie potencjału środków ochrony środowiska UE: budowanie zaufania poprzez większą wiedzę i lepsza zdolność reakcji, COM (2012) 95 final.

20 Por. H. Jans, Who is the Referee?..., s. 93; D. Krawczyk, Case Note: The Slovak Brown Bear Case: The ECJ Hunts for Jurisdiction and Environmental Plaintiffs Gain the Trophy, „Environmental Law Review” 2012, vol. 14, s. 57. 
W tym zakresie należy podkreślić, że Trybunał uznał wbrew literalnemu brzmieniu przywołanej deklaracji złożonej na podstawie art. 19 ust. 5 Konwencji z Aarhus, a więc wobec braku regulacji wdrażających na szczeblu unijnym art. 9 ust. 3 że jest właściwy do dokonania wykładni tego przepisu. Uzasadnienie stanowiska Trybunału jest jednak lakoniczne i sprowadza się do twierdzenia, że jeżeli „dany przepis może znaleźć zastosowanie zarówno do sytuacji objętych prawem krajowym, jak i do sytuacji objętych prawem Unii, niewątpliwe znaczenie ma to, by w celu uniknięcia przyszłych rozbieżności interpretacyjnych ów przepis był interpretowany w jednolity sposób, niezależnie od warunków, w jakich ma być stosowany"21. Trybunał nie skorzystał zatem z możliwości określenia, do jakiego stopnia wykonywanie kompetencji przez Unię jest wystarczające, aby uznać, że wydała ona przepisy w danej dziedzinie. Działania Trybunału warunkowane były zatem względami pragmatycznymi, uwzględniającymi przede wszystkim konieczność zapewnienia jednolitej wykładni postanowień Konwencji.

Kwestią, która może wzbudzać jeszcze większe wątpliwości, jest nałożenie przez Trybunał na sądy krajowe obowiązku interpretacji krajowych regulacji odnoszących się do dostępu do wymiaru sprawiedliwości w sposób zgodny z Konwencją z Aarhus. Niewątpliwie takie stanowisko Trybunału prowadzić miało do zwiększenia gwarancji procesowych „członków społeczeństwa”, o których mowa w art. 9 ust. 3, a w konsekwencji ochrony ich praw w postępowaniach krajowych ${ }^{22}$. Niemniej jednak Trybunał nie wskazał żadnej podstawy prawnej, z której wynikałby rzeczony obowiązek. Ponadto tak sformułowane stanowisko Trybunału zaciera różnicę pomiędzy bezpośrednią skutecznością normy prawnej a obowiązkiem tzw. zgodnej interpretacji. W praktyce, na kanwie stosowania art. 9 ust. 3 Konwencji pojawia się wątpliwość, czy nakaz zgodnej wykładni utożsamiać należy z nakazem tzw. wykładni prounijnej przepisów prawa

21 Por. pkt. 42 wyroku w sprawie C-240/09.

22 D. Szaściło, Glosa do wyroku TS z dnia 8 marca 2011 r., C-240/09, „Samorząd Terytorialny" 2011, nr 6, s. 84. 
krajowego ${ }^{23}$, która nie może prowadzić do rezultatów sprzecznych z obowiązującym prawem krajowym, czy też stanowi przyzwolenie do bezpośredniego stosowania tej normy przed sadami krajowymi ${ }^{24}$. Szczególnie dyskusyjne, w kontekście zasady autonomii proceduralnej państw członkowskich, wydaje się być przyjęcie drugiego stanowiska. Zasygnalizowane wątpliwości, wobec braku wyraźnych wskazówek Trybunału, mogą prowadzić do niepewności sytuacji procesowej skarżących ${ }^{25}$.

\section{PODSUMOWANIE}

Unia Europejska nie wdrożyła w pełni postanowień Konwencji z Aarhus w zakresie dostępu do wymiaru sprawiedliwości w sprawach dotyczących środowiska. Niemniej jednak dokonywana przez Trybunał Sprawiedliwości wykładnia art. 9 ust. 3 Konwencji z Aarhus zasługuje co do zasady na pozytywną ocenę. Dąży bowiem do zwiększenia gwarancji proceduralnych skarżących w postępowaniach przed sądami państw członkowskich, a w konsekwencji może przyczynić się do skuteczniejszego egzekwowania przepisów dotyczących ochrony środowiska.

Podkreślić przy tym należy, że nałożony przez Trybunał na sądy krajowe obowiązek dokonywania interpretacji regulacji krajowych w sposób zgodny z art. 9 ust. 3 Konwencji z Aarhus nie daje pełnych gwarancji osiągnięcia celu wskazanego w tym przepisie. Z tego względu, jeżeli Unia zamierza wypełnić podjęte zobowiązanie, pożądane jest zintensyfikowania prac legislacyjnych nad zapewnieniem lepszego dostępu do wymiaru sprawiedliwości w kwestiach dotyczących środowiska ${ }^{26}$.

23 Tak np. przyjął WSA w Poznaniu w wyroku z dnia 11 października 2012 w sprawie IV SA/Po 353/12, CBOSA.

24 J. H. Jans, Who is the Referee?..., s. 98.

25 Por. krytyczne uwagi Ch. Eckes, Environmental Policy "Outside-In": How the EU's Engagement with International Environmental Law Curtails National Autonomy, „German Law Journal” 2012, vol. 13, s. 1168.

26 Warto podkreślić, że zarówno instytucje unijne: Komisja (por. Commission initiative on Access to justice in environmental matters at Member State level 
Wobec braku działania unijnego ustawodawcy, ochrona praw organizacji zajmujących się ochroną środowiska określonych w art. 9 ust 3 Konwencji spoczywa na sądach państw członkowskich. Ze względu jednak na coraz większą liczbę skarg kierowanych do Komisji, jak również zwiększoną liczbę postępowań przed sądami krajowymi, w których bezpośrednio powoływana jest Konwencja, wskazane jest podjęcie pozalegislacyjnych działań ułatwiających realizację określonych w niej celów. Szczególną rolę może w tym obszarze odegrać Komisja, wykorzystując w ramach współpracy z sądami krajowymi, podobnie jak to czyni np. w sprawach z zakresu konkurencji, niewiążące instrumenty prawne (soft law).

\section{BIBLIOGRAFIA}

Barcz J., W sprawie bezpośredniego skutku przepisów TRIPS $w$ świetle prawa wspólnotowego(I), „Europejski Przegląd Sądowy” 2006, nr 2.

Baumgart Ł., Sukcesja prawnomiędzynarodowa pomiędzy Unią Europejska a wspólnotami europejskimi oraz innymi organizacjami międzynarodowymi, „Studia Prawnicze” 2011, z. 3/4.

Ciechanowicz-McLean J., Prawo i polityka ochrony środowiska, Warszawa 2009.

Eckes Ch., Environmental Policy “Outside-In": How the EU's Engagement with International Environmental Law Curtails National Autonomy, „German Law Journal” 2012, vol. 13.

Jans J. H., Who is the Referee? Access to Justice in a Globalised Legal Order, "Review of European Administrative Law” 2011, vol. 4 Issue 1.

Jendrośka J., Bar M., Implementation of the Aarhus Convention principles and other topical issues of EU environmental law as reviewed

in the field of EU environment policy, listopad 2013, Parlament i Rada (por. decyzję Parlamentu Europejskiego i Rady z dnia 29 listopada 2012 w sprawie ogólnego unijnego programu działań w zakresie środowiska do 2020 r. „Dobrze żyć w granicach naszej planety", COM(2012) 710 final.), jak i organy doradcze (tak np. Komitet Regionów w opinii z 30 listopada 2012 r. „W kierunku siódmego programu działań w zakresie środowiska - lepsze wdrażanie prawodawstwa UE dotyczącego środowiska naturalnego", Dz.Urz. UE C 17 z 19.1.2013, s. 30) dostrzegają taką potrzebę. 
in a critical analysis of the Yearbook of European Environmental Law - Vol. 4 i 5, „Environmental Liability Journal”, vol. 14 (5) 2006.

Kenig-Witkowska M. M., Prawo środowiska Unii Europejskiej: Zagadnienia systemowe, Warszawa 2011.

Kranz J., Wyrozumska A., Powierzenie Unii Europejskiej niektórych kompetencji a traktat fiskalny, „Państwo i Prawo” 2012, nr 7.

Krawczyk D., Case Note: The Slovak Brown Bear Case: The ECJ Hunts for Jurisdiction and Environmental Plaintiffs Gain the Trophy, „Environmental Law Review” 2012, vol. 14.

Lidbetter A., Depani N., The Aarhus Convention and Judicial Review, „Judicial Review” 2014, Vol. 19 Issue 1, s. 30-38, DOI: 10.5235/ JR.23.2.1

Micińska M., Udział społeczeństwa w ochronie środowiska. Instrumenty administracyjno - prawne, Torun 2011.

Müller B., Access to the Courts of the Member States for NGOs in Environmental Matters under European Union Law, „Journal of Environmental Law”, Nov 2011, Vol. 23 Issue 3.

Niedźwiedź M., Umowy międzynarodowe mieszane $w$ świetle prawa Wspólnoty Europejskiej, Warszawa 2004.

Szaściło D., Glosa do wyroku TS z dnia 8 marca 2011 r., C-240/09, „Samorząd Terytorialny” 2011, nr 6.

Kontakt e-mail:

akp@law.umk.pl 